\title{
25. K-Ar DATING OF BASALT FROM DSDP 163: LEG 16, DEEP SEA DRILLING PROJECT
}

\author{
Jack Dymond, Department of Oceanography, Oregon State University, Corvallis, Oregon
}

Two problems have prevented routine $\mathrm{K}-\mathrm{Ar}$ dating of deep-sea tholeiites: (a) trapped radiogenic argon and (b) submarine weathering. Several workers (Dalrymple and Moore, 1968; Funkhouser et al., 1968; Noble and Naughton, 1968) have reported the presence of excess argon in submarine basalts. The lack of equilibration of submarine basalts with atmospheric gases apparently results from rapid quenching of the magma under pressure. Dymond (1970), by analyzing the amount of argon at various levels in single basalt pillows, suggested that no excess radiogenic argon is present deeper than $5-10 \mathrm{~cm}$ inside a submarine volcanic flow. Submarine weathering appears to be largely a problem of potassium uptake. Comparative studies of rims and interiors of basalt fragments (Hart, S.R., 1969; Hart, R., 1970) show that the K-content of tholeiites increases by a factor of 2 to 3 with only modest weathering. These studies indicate that weathering does migrate inward from the sea-water/rock boundary, albeit irregularly due to cooling fractures. It appears, therefore, that deep drilling of basalt offers the best hope of recovering samples suitable for $\mathrm{K}-\mathrm{Ar}$ dating with respect to both the excess argon and the weathering problems. DSDP 163, which penetrated 18 meters into basalt, presented an opportunity to test the K-Ar dating requirements for drilling old basalts and to obtain a basement age for this location.

Table 1 contains the data for five individual $\mathrm{K}-\mathrm{Ar}$ determinations from near the bottom of the basalt core. The basalts themselves have been described in detail by Yeats et al. (this volume, Chapter 22). Megascopically, this portion of the core shows the least evidence (calcite veins, discoloration) of alteration by interaction with seawater. All samples lie within $7 \mathrm{~cm}$ of each other and all are whole rock determinations. One sample (163-29$4,72-74 \mathrm{~cm}$ ) was crushed to $50-100$ mesh size and vigorously agitated using an ultrasonic probe. This treatment was performed because the thin section of this portion of the core showed the presence of a microcrystalline claylike mineral or "smectite." Much of the smectite lies along grain boundaries of feldspar and pyroxene; however, some appears to be a replacement of olivine. This phase could be the result of low-temperature alteration of the basalt or late-stage deuteric alteration of the primary minerals. The crushing to a size approaching the size of individual crystals, ultrasonic treatment, and decantation was judged a suitable means of partially removing this phase and testing its effect on the $\mathrm{K}-\mathrm{Ar}$ age. The decrease in $\mathrm{H}_{2} \mathrm{O}$ and potassium in the crushed sample suggests that some of the "smectite" was removed. Within experimental errors, however, all ages are equal and average $49.8 \mathrm{my}$. The relatively poor precision results from the low percentage of radiogenic argon. Since the samples contain a normal amount of air argon $\left(10^{-7} \mathrm{cc} / \mathrm{g}\right)$, the low radiogenic component is a product of exceedingly low potassium content.

Based solely on the age information and thin section analysis, the age looks reasonable. The K-Ar data for the crushed sample suggest that the smectite has not markedly affected the potassium content. The potassium content of the whole rock suggests little alteration, as it is among the lowest potassium values reported for subalkaline tholeiites. But with respect to the biostratigraphic age of the overlying sediments, the age appears too young. The overlying sediments have relatively non-diagnostic fossils; however, a Campanian age (70-76 my; Chaper 10) is fairly certain. The magnetic anomaly pattern at DSDP 163 is obscure; nonetheless, basement ages obtained on Leg 9 and on DSSP 159-161 indicate a mean spreading rate for the Clarion-Clipperton block of $8-9 \mathrm{~cm} /$ year. This would yield a basement age of 65-70 my for DSDP 163 .

If an age of 65-75 my is correct, then either the basalt dated is intrusive or the $50 \mathrm{my}$ age is in error. The petrographic evidence is strongly against an intrusive origin. The 7.4 meters of basalt recovered can be divided into

TABLE 1

K-Ar Data for Basalt from DSDP 163, Core 29, Section 4, Approximately 290 Meters Below Sea Floor

\begin{tabular}{ccccccc}
\hline $\begin{array}{c}\text { Depth in } \\
\text { Section } \\
(\mathrm{cm})\end{array}$ & $\mathrm{H}_{2} \mathrm{O}^{-}$ & $\mathrm{H}_{2} \mathrm{O}^{+}$ & $\mathrm{K}$ & $\begin{array}{c}\text { Argon-40 } \\
(\mathrm{cc} / \mathrm{g})\end{array}$ & $\begin{array}{c}\text { Radiogenic } \\
\mathrm{Ar}^{40} \\
(\%)\end{array}$ & $\begin{array}{c}\text { Age } \\
(\mathrm{my})^{\mathrm{a}}\end{array}$ \\
\hline $67-69$ & 0.874 & 0.715 & 0.0492 & $9.63 \times 10^{-8}$ & 9 & $48.3 \pm 5.2$ \\
$72-74$ & & & 0.0525 & $1.11 \times 10^{-7}$ & 8 & $51.9 \pm 6.5$ \\
$72-74$ & & & 0.0525 & $1.09 \times 10^{-7}$ & 10 & $51.2 \pm 4.7$ \\
$67-74$ & 0.393 & 0.730 & 0.0431 & $8.36 \times 10^{-8}$ & 5 & $47.9 \pm 9.4$ \\
(crushed) & & & & & & \\
\hline
\end{tabular}

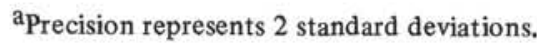


seven units separated by 1-to 2-cm zones of glass. The individual units vary from 14 to $470 \mathrm{~cm}$ in thickness and are bounded by glass zones which dip at 15-17 degrees. The most probable mechanism of emplacement is as individual flows in the case of the thicker units and pillows for the thinner units. If the basalt is extrusive, then what are the mechanisms for producing a low age? Argon diffusion is a possibility. Semiquantitative microprobe analyses of the sample by Dr. Daniel Weill, University of Oregon, indicate that most of the potassium is concentrated along grain boundaries and in the smectite. Regardless of whether this phase forms in the last stages of crystallization of the magma or by low-temperature alteration, its microcrystalline nature may result in inadequate argon retentivity for a sample $75 \mathrm{my}$ in age. Potassium addition by weathering would also give a low age. Water content of the rock is somewhat higher than that of young surficial rocks from the mid-ocean ridges-possible evidence of low-temperature alteration.

It is difficult to distinguish between these possibilities; however, the distinction is important with respect to the value of K-Ar dating of basalts obtained by the Deep Sea Drilling Project in the future. If the low age results from minor weathering, then deeper drilling could eliminate the problem. If, on the other hand, the low age is the result of concentration of potassium in poorly crystalline phases formed by deuteric alteration, deeper drilling will not help. Perhaps $\mathrm{Ar}^{40} / \mathrm{Ar}^{39}$ dating of this sample could solve the problem.

\section{ACKNOWLEDGMENTS}

I wish to thank Roger Hart and Dr. G. Ross Heath for their helpful comments and Dr. Daniel Weill for measuring the potassium content by microprobe analysis. This work was supported by National Science Foundation Grant GA-27548.

\section{REFERENCES}

Dalrymple, G.B. and Moore, J.G., 1968. Argon-40: Excess in submarine pillow basalt from Kilauea Volcano, Hawaii. Science, 161, 1132.

Dymond, J., 1970. Excess argon in submarine basalt pillows. Bull. Geol. Soc. Am. 81, 1229.

Funkhouser, J.G., Fisher, D.E. and Bonatti, E. 1968. Excess argon in deep-sea rocks. Earth Planet. Sci. Letters. 5, 95.

Hart, R., 1970. Chemical exchange between sea water and deep ocean basalts. Earth Planet. Sci. Letters. 9, 269.

Hart, S.R., 1969. K, Rb, Cs contents and K/Rb, K/Cs ratios of fresh and altered submarine basalts. Earth Planet. Sci. Letters. 6, 295.

Noble, C.S. and Naughton, J.J., 1968. Deep-ocean basalts: Inert gas content and uncertainties in age dating. Science. 162, 265. 